\title{
MARTIN HINDS
}

MARTIN HINDS had friends all over the world, and his untimely death on 1 December 1988, at the age of 47 , was the cause of much sorrow. Those who knew and loved him are aware how much the world has lost in personal distinction and promise partly unfilled, but there is some consolation in the thought of what he had already achieved as a teacher and a writer from whom publications had begun to pour during the last few years of his life.

Born in 1941, Martin studied Arabic at the School of Oriental and African Studies in London, and obtained his B.A. and Ph.D. degrees there. His thesis, on "The Early History of Islamic Schism in Iraq," was never published in full, but two articles based on it- "The Murder of the Caliph "Uthman" and "Kufan Political Alignments" (both published in the International Journal of Middle East Studies) - are of lasting value for our understanding of the political history of early Islam. His remarkable combination of qualities was already shown clearly in them: precise and comprehensive knowledge of the sources and an unusual grasp of the nature of political activity. I remember one of the first occasions I met him. He gave a talk to the Near East History Group at Oxford about the thesis on which he was then working, and I was struck by his power of bringing political events long past to life once more; as he talked, the expressions of his voice and face seemed to re-create the words and gestures of the ancient Arabian politicians. This imaginative insight into Arab life, formed and enriched by long residence in Arab countries and many friendships, was not the least of his gifts as a scholar and teacher. I noticed it again much later, when we worked together as historical consultants for the television series The Arabs; he showed a deep and patient understanding of the problems of filming in Arab countries and the arcane rites of the TV industry.

He taught Arabic at the School of Oriental and African Studies from 1963 to 1966, and then at Cambridge until his death. For much of that time his publication was limited, but it was not for lack of energy or hard work. He was a devoted and skillful teacher, much admired by his students, and an active member of his college, Trinity Hall, of which he became a Fellow in 1972 and where he took a full part in the corporate life, holding several administrative offices. His friends may best remember him in his room in college; he was always ready to interrupt his work for conversation or consultation, but as one left one could be certain that he would be back at his desk among his books, in that absorbed and sustained solitude which is the necessary condition of serious scholarly work.

All the time there was another life going on, in Cairo, where he had a long-standing relationship with the American University. For two years he was executive director of the Center for Arabic Studies Abroad, where young American scholars were trained as Arabists. He was also involved in a large-scale project of compiling a dictionary of Egyptian Arabic, in collaboration with El-Said Badawi. Attended by many difficulties, long 
awaited and long delayed, the work finally appeared in 1986, published by the Librairie du Liban in Beirut. It was at once recognized as a remarkable and even a unique book. Its subject is the spoken Arabic through which Egyptians live, and it attempts to "describe the language as it is now, rather than as it was, as it may be in the future, or as some would like it to be." It is based not so much on previous dictionaries as on oral evidence transcribed from tape-recordings, and it looks at Egyptian Arabic as an independent system, having complex relations with the written language. It shows a special concern with technical terms used in traditional areas of activity, in particular those of handicrafts. Thus it serves as a repertoire of the words and phrases through which Egyptians express their perceptions of their world and their lives. By implication, it is a new Manners and Customs of the Modern Egyptians, an accurate depiction of a living society.

The year of the publication of the dictionary was an annus mirabilis in his life as a scholar. It saw also the appearance of two other books, both written in collaboration. Arabic Documents from the Ottoman Period from Qasr Ibrim, prepared in collaboration with Hamdi Sakkout, contained texts and translations of documents discovered in Upper Egypt by an expedition organized by the Egypt Exploration Society. God's Caliph: Religious Authority in the First Centuries of Islam, published by the Cambridge University Press, was written together with Patricia Crone. This is an attempt to revise certain generally accepted ideas about the early history of the Muslim community. Its argument is that the early caliphs were regarded as possessing religious as well as political authority, being "both head of state and ultimate source of religious law"; the early concept of authority, the authors suggest, was nearer that associated with Shi'ism than with the Sunni view as it later developed. This thesis has aroused considerable interest. In a review published in the Times Literary Supplement of 3 July 1987, Fred M. Donner concluded that, although he believed the authors had exaggerated the degree of agreement existing in early Islamic society on matters of religious authority, their book was "a scholarly contribution of major importance ... the best-documented, most penetrating and most thought-provoking study of early Islamic religiopolitical concepts to date."

Those who knew Martin rejoiced in this outburst of publication and looked forward to the appearance of other works already in progress or planned: a second volume of documents from Qasr Ibrim, on which he was working with V. L. Ménage, a volume in the series of English translations of al-Tabari's history, and more books to be written together with Patricia Crone. The lymph cancer, which first showed itself in 1987 and finally killed him after many months of false hopes, has ended the production, but has not dimmed the memory of a steadfast friend, a dedicated teacher, and a scholar of remarkable powers and great attainments.

Albert Hourani 